\title{
PHENOTYPE VARIABILITY OF EXTERNAL QUALITY TRAITS OF FERTILE EGGS OF PARTRIDGE ITALIAN BREAD IN SEMI EXTENSIVE BREEDING SYSTEM
}

\author{
V. Đermanović ${ }^{1}$, S. Mitrović ${ }^{1}$ \\ ${ }^{1}$ University of Belgrade, Faculty of Agriculture, Institute of Zootechnic, Nemanjina 6, 11080 Zemun, \\ Republic of Serbia. \\ *Corresponding author: djermanovic@agrif.bg.ac.rs \\ Original scientific paper
}

Abstract: In this paper results of research of external quality traits of the fertile eggs of Partridge Italian bread in semi extensive system are shown. Research was conducted on sample of 64 eggs, divided in to two groups according to the weight. First group was eggs weighing up to the $60 \mathrm{~g}(\leq 60 \mathrm{~g})$ and second group eggs weighing above $60 \mathrm{~g}(>60 \mathrm{~g})$. Aim of the research was to determine influence of the weight of the eggs to the external quality traits of fertile eggs, such as weight, length, width and shape index of the eggs in quoted breeding system. Obtained result points to the fact that Partridge Italian in semi extensive system achieves satisfying results in regard of the basic external characteristics of egg quality. Results of the conducted research show that it is needed to give higher attention to the quality of eggs used for planting, to the breeding direction, improvement of the productive and reproductive traits, and therefore to preservation of the genetic potential of different breeds and strains of chicken.

Key words: Partridge Italian hen, fertile eggs, external egg traits

\section{Introduction}

Lately egg quality, especially fertile egg quality of different breeds of chicken and their mixes, compared to hybrids is becoming an object of research of many authors in the world (Sabri et al., 1999; Farooq et al., 2001; Islam et al., 2002; Monira et al., 2003; Anderson et al., 2004; Pohle and Cheng, 2009), and in our country (Mitrović et al., 2011; Đermanović et al., 2012; Dermanović et al., 2013). These researches are specially interesting because of growing organic poultry production. Reason for that is because pure breeds are much better for organic production than hybrids. Therefore Mitrović et al. (2005) and Đermanović et al. (2012) cite that autochthonous breeds of animals are not given proper attention compared to other breeds, especially commercial breeds and hybrids, laying hen hybrids even though autochthonous breeds and strains are actual 
product of the environment and breeding conditions in specific area. Mitrovic et al. (2011) quotes that next to the breeding system in poultry organic production one of the main points should be breed choice, or the strain choice which will be used for egg and meat production. When starting and organizing the organic poultry production one should give advantage to autochthonous breeds which are already adapted to the local breeding conditions and are immune to area specific diseases.

Having in mind that in semi extensive and extensive system of breeding next to the consumer eggs, fertile eggs are being produced special attention should be given to quality assessment and above all to the external quality traits and their incubational values. That is why aim of this research was examining of the external quality traits (weight, length, width and shape index) of the fertile eggs that can be used for reproduction produced in semi extensive system.

\section{Material and Methods}

In order to determine external quality of the Partridge Italian breed eggs research was conducted on "Galijaš" farm. Main scope of work on that farm is production of consuming and fertile eggs which were used as experimental material. Experimental flock was kept within the economic yard where different fruits were planted, and it was fed per will with appropriate concentrate mixtures, next to widely available pasture corn grain was supplied along with grinded corn and wheat.

In the experiment 64 fertile eggs were used, they were chosen by random sample method. There were two groups of 32 eggs divided in to two categories according to the weight, first group was eggs weighing up to the $60 \mathrm{~g}(\leq 60 \mathrm{~g})$ and second group eggs weighing above $60 \mathrm{~g}(>60 \mathrm{~g})$. During the production cycle following parameters were determined: egg weight, length and width of the eggs, based on which shape index was calculated [Shape index $=$ (width/length) $\mathrm{x} 100$ ]. Egg weight was determined by the scale with accuracy of $\pm 1 \mathrm{~g}$, while length and width by special scale with accuracy of $\pm 0.02 \mathrm{~mm}$. Measuring of the parameters was conducted on eggs kept between 3 and 5 days.

For all monitored parameters usual statistic methods (arithmetic mean, arithmetic mean error, standard deviation and variation coefficient) were calculated. Determined differences between monitored parameters were calculated with T-test. Based on data obtained by calculating correlations, interconnection between followed parameters was determined. Statistical data was calculated in SAS/STAT (SAS Institute, 2000) program. 


\section{Results and Discussion}

Average values and variability as well as significance of the differences of the monitored quality parameters for the experimental genotype of chicken bread in semi extensive breeding system are shown in tables 1 and 2 .

Table 1. Average values and variability of the examined parameters of eggs quality

\begin{tabular}{|c|c|c|c|c|c|}
\hline Parameters & Eggs group & $\bar{x}$ & $\mathrm{~S}$ & $\mathrm{~S} \bar{x}$ & C.V. \\
\hline \multirow{2}{*}{ Eggs weight, g } & I & 59.00 & 2.24 & 0.40 & 3.80 \\
\cline { 2 - 6 } & II & 65.50 & 3.03 & 0.54 & 4.63 \\
\hline \multirow{2}{*}{ Eggs length, mm } & I & 54.55 & 2.38 & 0.42 & 4.36 \\
\cline { 2 - 6 } & II & 56.90 & 2.03 & 0.36 & 3.57 \\
\hline \multirow{2}{*}{ Eggs width, mm } & I & 41.65 & 1.14 & 0.20 & 2.74 \\
\cline { 2 - 6 } & II & 42.65 & 0.56 & 0.10 & 1.31 \\
\hline \multirow{2}{*}{ Width length ratio, \% } & I & 76.35 & 2.58 & 0.46 & 3.38 \\
\cline { 2 - 6 } & II & 74.96 & 2.32 & 0.41 & 3.09 \\
\hline
\end{tabular}

Table 2. Significance of differences tested parameters of eggs quality

\begin{tabular}{|c|c|c|c|c|}
\hline Parameters & $\bar{x}_{\mathrm{I}}$ & $\bar{x}_{\text {II }}$ & $\bar{d}$ & Significance \\
\hline Eggs weight, g & 59.00 & 65.50 & 6.50 & $9.758^{* * *}$ \\
\hline Eggs length, mm & 54.55 & 56.90 & 2.35 & $4.250^{* * *}$ \\
\hline Eggs width, mm & 41.65 & 42.65 & 1.00 & $4.454^{* * *}$ \\
\hline Width length ratio, \% & 76.35 & 74.96 & 1.39 & $2.266^{*}$ \\
\hline
\end{tabular}

From data shown in table 1 it is notable that average egg weight for first group ( $\leq 60 \mathrm{~g}$ ) was $59.00 \mathrm{~g}$, and for second group $65.50 \mathrm{~g}$. Compared to the egg weight, length $(54.55 \mathrm{~mm}-56.90 \mathrm{~mm})$ and width $(41.65 \mathrm{~mm}-42.65 \mathrm{~mm})$ shown much less differences but they were statistically very significant $(\mathrm{P}<0.001)$. However, when it comes to shape index difference between monitored groups was $1.39 \%$ (76.35\% - 74.96\%) and it was statistically significant $\mathrm{P}<0.05$ (table 2 ). Next to the above stated, from data in the table 1, it is visible that eggs from first group had higher variability (C.V) compared to the eggs originating from second group in length, width and shape index, while second group had higher variability in egg weight (4.63) compared to the eggs from first group (3.80).

Research results of the most of the authors were refereeing mainly to the typical representative of light weight chicken, the Leghorn breed. Therefore approximate values of researched parameters for leghorn breed bread in same system was determined by Đermanović et al. (2013). Moreover, same results were obtained by Islam et al. (2002) who also determined that average weight of fertile 
eggs for leghorn breed was $59.48 \mathrm{~g}$, though Sabri et al. (1999) determined lower average weight for leghorn fertile eggs (54.3 g). Anderson et al. (2004) determined for leghorn breed that average weight and width were similar as for other authors, while lengths were slightly different and shape index was slightly lower. More detailed research was conducted by Monira et al. (2003), who determined that eggs originating from leghorn breed in different periods of keeping $(1,7,14$ and 21 day) averagely weighed $64.00 \mathrm{~g}$, for 7 days old eggs $52.20 \mathrm{~g}$. Same authors determined slightly higher lengths for eggs kept one day $(6.12 \mathrm{~cm})$, while value of the same parameter for 7 day old eggs was $5.56 \mathrm{~cm}$. When it comes to width quoted authors determined similar values $(4.28 \mathrm{~cm}-1$. day; $4.10 \mathrm{~cm}-7$. day), while for the shape index they determined much lower values $(69.99 \%-1$. day; $73.80 \%-7$. day). Pohle and Cheng (2009) researched influence of breeding system on physiological characteristics of leghorn laying hens and concluded that average egg weight in cage system was $54.27 \mathrm{~g}$ (30. weeks of age) and $60.24 \mathrm{~g}$ (60. weeks of age).

Next to determined absolute and relative variations for researched egg quality traits for planting eggs of Partridge Italian breed, coefficients of phenotype correlation were calculated between quoted parameters (table 3 ).

Table3. Phenotype correlation between examined parameters of eggs quality

\begin{tabular}{|c|c|c|c|c|c|}
\hline Parameters & Eggs group & E.We. & E.L. & E.Wi. & W.L.R. \\
\hline \multirow{2}{*}{ E.We. } & I & 1.000 & $0.871^{* * *}$ & $0.521^{* *}$ & $-0.725^{* * *}$ \\
\cline { 2 - 6 } & II & 1.000 & $0.668^{* * *}$ & $0.797^{* * *}$ & $-0.404^{*}$ \\
\hline \multirow{2}{*}{ E.L. } & I & - & 1.000 & $0.635^{* * *}$ & $-0.784^{* * *}$ \\
\cline { 2 - 6 } & II & - & 1.000 & $0.401^{*}$ & $-0.930^{* * *}$ \\
\hline \multirow{2}{*}{ E.Wi. } & I & - & - & 1.000 & $-0.020^{\text {ns }}$ \\
\cline { 2 - 6 } & II & - & - & 1.000 & $-0.037^{\text {ns }}$ \\
\hline \multirow{2}{*}{ W.L.R. } & I & - & - & - & 1.000 \\
\cline { 2 - 6 } & II & - & - & - & 1.000 \\
\hline
\end{tabular}

${ }^{*} \mathrm{P}<0.001 ;{ }^{* *} \mathrm{P}<0.01 ;{ }^{*} \mathrm{P}<0.05 ;{ }^{\mathrm{ns}} \mathrm{P}>0.05$.

Based on determined correlation coefficients between analyzed parameters (table 3) it is visible that with increase of egg weight, for both researched groups, the length of the egg is being statistically significantly $(\mathrm{P}<0.001)$ increased. Similar to the egg length and other researched parameters statistically significant correlation was determined, though on different levels for different parameter ( $\mathrm{P}<0.001 ; \mathrm{P}<0.01 ; \mathrm{P}<0.05)$, in dependence of the weight group of the eggs. It has, also, been determined that with increase of the length the width of the egg is increased which was statistically significant $(\mathrm{P}<0.001-$ I group; $\mathrm{P}<0.05-$ II group), and correlation between quoted parameters was more expressed for the eggs that belong to the first group. Moreover, data from table 3 further shows that between shape index and other researched parameters negative statistically significant $(\mathrm{P}<0.001$ - egg weight I group and length of the eggs for both groups; $\mathrm{P}<0.05$ - weight of the eggs II group) correlation coefficients exist, and that 
between width and shape index negative correlation coefficients, which weren't statistically significant $(\mathrm{P}>0.05)$, were determined.

Farooq et al. (2001) determined similar results for Rhode Island Red breed, Dermanović et al. (2012) for New Hampshire and for autochthonous breed Sombor Crested, and Đermanović et al. (2013) for Leghorn breed.

\title{
Conclusion
}

Based on obtained results it can be concluded that in semi extensive breeding system Partridge Italian can be successfully bread, providing good fertile and consumer eggs. The conclusion is backed up with research results, that, average egg weight is between $59.00 \mathrm{~g}$ and $65.50 \mathrm{~g}$, and shape index between $76.35 \%-74.96 \%$, all that is being confirmed by calculated phenotype correlation coefficients between monitored parameters for both weight groups.

Partridge Italian has shown satisfying results in planting eggs production, which points out that in semi extensive system next to the autochthonous breeds other chicken breeds can be bread. Special attention should be given, above all, to the increase of the quality of fertile eggs and to the further development of the productive and reproductive traits of specific genotype.

\section{Acknowledgement}

The authors are grateful to the Ministry of Education, Science and Technological Development of the Republic of Serbia for sponsoring part of the study within project TR-31033.

\section{Fenotipska varijabilnost spoljašnjih osobina kvaliteta priplodnih jaja jarebičaste italijanke gajene $u$ poluekstenzivnom sistemu}

\author{
V. Đermanović, S. Mitrović
}

\section{Rezime}

U radu su izloženi rezultati ispitivanja spoljašnjih osobina kvaliteta priplodnih jaja jarebičaste italijanke gajene u poluekstenzivnom sistemu držanja. Ispitivanja su izvršena na uzorku od 64 jajeta, podeljenih u dve težinske grupe i to: I grupa - jaja težine do $60 \mathrm{~g}(\leq 60 \mathrm{~g})$ i II grupa - jaja težine preko $60 \mathrm{~g} \mathrm{(>60} \mathrm{g).} \mathrm{Cilj}$ istraživanja je bio da se ispita uticaj težinske grupe jaja na spoljašnje osobine kvaliteta priplodnih jaja, kao što su težina, dužina, širina i indeks oblika jaja u navedenom sistemu držanja.

Dobijeni rezultati ukazuju na činjenicu da jarebičasta italijanka $u$ poluekstenzivnom sistemu gajenja ostvaruje zadovoljavajuće rezultate u pogledu 
osnovnih karakteristika spoljašnjeg kvaliteta jaja. Rezultati sprovedenih istraživanja ukazuju na to da je potrebno posvetiti veću pažnju ispitivanju kvaliteta jaja za nasad, pravcu odgajivanja, poboljšanju proizvodnih i reproduktivnih sposobnosti, a samim tim i očuvanju genetskog potencijala različitih rasa i sojeva kokoši.

\section{References}

ANDERSON K.E., THARRINGTON J.B., CURTIS P.A., JONES F.T. (2004): Shell Characteristics of Eggs from Historic Strains of Single Comb White Leghorn Chickens and the Relationship of Egg Shape to Shell Strength. International Journal of Poultry Science, 3(1): 17-19.

ĐERMANOVIĆ V., ĐEKIĆ V., MITROVIĆ S., RAJOVIĆ M., MITROVIĆ M., PANDUREVIĆ T. (2012): Comparative review of brooding eggs of the Sombor Crested and New Hampshire breeds bred in semi extensive breeding system. Proceedings of Research Papers, Vol. 18, 3-4, 123-130.

ĐERMANOVIĆ V., MITROVIĆ S., ĐEKIĆ V., MITROVIĆ M. (2013): Quality assessment of Leghorn breeding eggs reared in semi extensive breeding system. Proceedings of Research Papers, Vol. 19, 3-4, 173-178.

FAROOQ M., DURRANI F.R., ALEEM M., CHAND N., MUQARRAB A.K. (2001): Egg Traits and Hatching Performance of Desi, Fayumi and Rhode Island Red Chickens. Pakistan Journal of Biological Sciences, 4(7): 909-911.

ISLAM M.S., HOWLIDER M.A.R., KABIL F., ALAM J. (2002): Comparative Assessment of Fertility and Hatchability of Barred Plymouth Rock, White Leghorn, Rhode Island Red and White Rock Hen. International Journal of Poultry Science, 1(4): 85-90.

MITROVIĆ S., ĐERMANOVIĆ V., PUPAVAC S., OSTOJIĆ Đ., RAJOVIĆ M. (2011): Incubation value of eggs domestic strains grown in chicken rural areas our country. Proceedings of Research Papers, Vol. 17, 3-4, 149-156.

MITROVIĆ S., BOGOSAVLJEVIĆ-BOŠKOVIĆ S., TOLIMIR N., ĐERMANOVIĆ V. (2005): The Regional Genetics Resources in our Country. Živinarstvo, 6-7, 16-22.

MONIRA K.N., SALAHUDDIN M., MIAH G. (2003): Effect of Breed and Holding Period on Egg Quality Characteristics of Chicken. International Journal of Poultry Science, 2: 261-263.

POHLE K., CHENG H.W. (2009): Comparative effects of furnished and battery cages on egg production and physiological parameters in White Leghorn hens. Poultry Science, 88: 2042-2051.

SABRI H.M., WILSON H.R., HARMS R.H., WILCOX C.J. (1999): Genetic parameters for egg and related characteristics of White Leghorn hens in a subtropical environment. Genetics and Molecular Biology, 22, 2, 183-186.

SAS INSTITUTE (2000): SAS (Statistical Analysis System). User's guide: Statistics. SAS Institute Inc. Cary, NC. 